J. Dairy Sci. 97:7927-7939

http://dx.doi.org/10.3168/jds.2014-8216

(C) American Dairy Science Association ${ }^{\circledR}, 2014$.

\title{
Associations between CXCR1 polymorphisms and pathogen-specific incidence rate of clinical mastitis, test-day somatic cell count, and test-day milk yield
}

\author{
Joren Verbeke, ${ }^{* 1}$ Mario Van Poucke, $†$ Luc Peelman, $†$ Sofie Piepers, ${ }^{*}$ and Sarne De Vliegher ${ }^{*}$ \\ *M-team and Mastitis and Milk Quality Research Unit, Department of Reproduction, Obstetrics, and Herd Health, and \\ †Animal Genetics Laboratory, Department of Nutrition, Genetics and Ethology, Faculty of Veterinary Medicine, Ghent University, 9820 Merelbeke, \\ Belgium
}

\section{ABSTRACT}

The CXCR1 gene plays an important role in the innate immunity of the bovine mammary gland. Associations between single nucleotide polymorphisms (SNP) CXCR1c.735C $>\mathrm{G}$ and c.980A $>\mathrm{G}$ and udder health have been identified before in small populations. A fluorescent multiprobe PCR assay was designed specifically and validated to genotype both SNP simultaneously in a reliable and cost-effective manner. In total, 3,106 cows from 50 commercial Flemish dairy herds were genotyped using this assay. Associations between genotype and detailed phenotypic data, including pathogen-specific incidence rate of clinical mastitis (IRCM), test-day somatic cell count, and test-day milk yield (MY) were analyzed. Staphylococcus aureus IRCM tended to associate with SNP c.735C $>$ G. Cows with genotype c.735GG had lower Staph. aureus IRCM compared with cows with genotype c.735CC (rate ratio $=$ $0.35,95 \%$ confidence interval $=0.14-0.90$ ). Additionally, a parity-specific association between Staph. aureus IRCM and SNP c.980A $>$ G was detected. Heifers with genotype c.980GG had a lower Staph. aureus IRCM compared with heifers with genotype c.980AG (rate ratio $=0.15,95 \%$ confidence interval $=0.04-0.56$ ). Differences were less pronounced in multiparous cows. Associations between CXCR1 genotype and somatic cell count were not detected. However, MY was associated with SNP c.735C $>$ G. Cows with genotype c.735GG out-produced cows with genotype c.735CC by $0.8 \mathrm{~kg}$ of milk/d. Results provide a basis for further research on the relation between CXCR 1 polymorphism and pathogen-specific mastitis resistance and MY.

Key words: CXCR1 single nucleotide polymorphism, dairy cow, udder health, milk yield

Received April 8, 2014.

Accepted September 10, 2014.

${ }^{1}$ Corresponding author: Joren.Verbeke@UGent.be

\section{INTRODUCTION}

Mastitis, an inflammation of the mammary gland mostly caused by bacterial IMI, impairs milk quality and production and increases the culling probability of dairy cows substantially (Beaudeau et al., 1995; Hortet et al., 1999; Ma et al., 2000; Santos et al., 2003; Seegers et al., 2003). The disease can be accompanied by local or systemic symptoms [clinical mastitis (CM)] or present itself without visible symptoms [subclinical mastitis (SM)]. In absence of clinical symptoms, mastitis can be detected by an increase in the concentration of somatic cells in milk (Schukken et al., 2003).

Resistance to mastitis is genetically determined (Detilleux, 2009), making a decrease in the incidence of mastitis by breeding a possibility (Windig et al., 2010). Identification of genetic polymorphisms linked with mastitis resistance would allow evaluation of the genetic make-up of male and female breeding animals for udder health, even before their offspring is born (Ogorevc et al., 2009). Polymorphisms in genes involved in the recognition of pathogens, recruitment of immune cells toward site of infection, elimination of the pathogens, and resolution of the inflammatory response are potential genetic markers for mastitis resistance (Pighetti and Elliott, 2011). In a recent genome-wide association study, polymorphisms located near CXCR1 and $C X C R 2$ were highly associated with occurrence of $\mathrm{CM}$ (Sodeland et al., 2011). The latter genes encode the 2 receptors present on PMNL for IL-8 (CXCL-8), named chemokine (C-X-C motif) receptor 1 and 2 (CXCR1 and CXCR2). Binding of IL-8 causes chemotaxis, increases activity, and inhibits apoptosis of PMNL (Barber and Yang, 1998; Kettritz et al., 1998; Mitchell et al., 2003).

Polymorphisms in the coding region of CXCR1 have been described (Pighetti et al., 2012; Verbeke et al., 2012). Eight of the detected SNP were nonsynonymous. The most frequently studied SNP, located at position 735 relative to the start codon $[$ c. $735 \mathrm{C}>\mathrm{G}$ (rs208795699)], causes an AA change (p.His245Glu) in the third intracellular loop of the receptor and was in full linkage disequilibrium with nonsynonymous SNP 
c.37A $>\mathrm{T} \quad(\mathrm{rs} 380621468), \quad$ c.38T $>\mathrm{A} \quad(\mathrm{rs} 110296731)$, and c.68G $>\mathrm{A}$ (rs133273369), causing changes in the N terminus (p.Ile13Tyr and p.Gly23Glu). Single nucleotide polymorphisms c.980A $>\mathrm{G} \quad$ (rs43323012) and c.995A $>\mathrm{G}$ (rs43323013) cause changes in the Cterminus (p.Lys327Arg and p.His332Arg) and were in full linkage disequilibrium with SNP c.337G $>$ A (rs207564206), causing a change in the first extracellular loop (p.Val113Ile). The SNP c.365T >C (rs211042414) encodes for p.Val122Ala in the third transmembrane domain (Verbeke et al., 2012). Amino acid changes potentially influence receptor activity through ligand binding, G-protein-related signaling, or receptor internalization (reviewed in Pighetti et al., 2012). Functional effects have yet to be studied. Additionally, (linked) polymorphisms could affect gene expression (Leyva-Baca et al., 2008a). Because of the results of the genome-wide association study and the important innate immune function of $C X C R 1$, it is reasonable to believe that $C X C R 1$ polymorphisms alter mastitis resistance.

Youngerman et al. (2004) detected associations between SNP c.735C $>\mathrm{G}$ and the incidence of SM, SCS, and milk yield (MY). Holstein c.735CC cows showed a higher incidence of SM and higher MY compared with c.735GG cows. Additionally, c.735GG cows had lower SCS compared with c.735CG cows. The association with SCS was confirmed later in an Irish cow population (Beecher et al., 2010). Galvão et al. (2011) detected lower MY and higher incidence rate of clinical mastitis (IRCM) in c.735GG cows. Because innate immune responses heavily depend on the invading mastitis pathogen (Bannerman et al., 2004; Schukken et al., 2011), associations between polymorphisms in innate immune genes and udder health are ideally studied using pathogen-specific data. Recently, we revealed a pathogen group-specific association between SNP c. $980 \mathrm{~A}>\mathrm{G}$ and the odds of IMI in early lactating heifers: c.980AG heifers were less likely to have IMI due to major mastitis pathogens (e.g., Staphylococcus aureus and Streptococcus uberis) compared with c.980GG heifers, but were not less likely to have IMI by CNS still considered as minor pathogens (Verbeke et al., 2012). In our study, associations between SNP c.735C $>$ G and c.980A $>\mathrm{G}$ and pathogen-specific IRCM, test-day SCC, and test-day MY were studied using a fluorescent multiprobe PCR assay that was specifically designed and validated to genotype a large number of cows in a reliable, fast, and cost-effective manner.

\section{MATERIALS AND METHODS}

\section{Herds and Animals}

Sixty-seven Flemish dairy producers were invited to participate in a 1-yr cohort study to estimate the pathogen-specific IRCM in Flanders (Verbeke et al., 2014). All participating herds $(\mathrm{n}=53)$ were visited at the beginning of the study in September or October 2012 by the first author. At that time, the study details were discussed with the producers and herd veterinarians, and blood samples of all lactating heifers and cows were taken. From then on, producers were asked to take a milk sample of each quarter showing signs of CM during the 12-mo study period (see further). To be able to include data of early lactating heifers, participating herds were revisited between February and March 2013 also by the first author. At that time, heifers that had calved between both visits were blood sampled. Data of 3 herds were omitted from the analysis along the study period because producers stopped sampling cases halfway through the study.

In total, 3,106 animals from 50 herds were blood sampled ranging between 18 and 250 per herd. Cowlevel records [birth date, calving date(s), parity, culling date, and sire and dam (both when available)] were retrieved from DHI records for herds participating in the DHI program organized by the Cattle Breeding Organization (Oosterzele, Belgium; $\mathrm{n}=32$ ) or from the identification and registration system of the Animal Health Service Flanders (DGZ Vlaanderen, Drongen, Belgium) for other herds $(\mathrm{n}=18)$.

\section{Phenotypic Records}

CM (Full Data Set, 50 Herds, 3,106 Cows). Producers were asked to take a milk sample from each quarter showing signs of CM during the 12-mo survey period. Signs of CM were defined as visible abnormalities of the udder or milk indicating udder inflammation. Sampling date and cow identification were recorded. Samples were frozen on farm and collected by the herd veterinarian. A courier of the Animal Health Service Flanders transported the samples from the veterinary practice to the Milk Control Center Flanders (Lier, Belgium) where bacteriological culture was performed according to National Mastitis Council standards (National Mastitis Council, 1999). From each thawed sample, $10 \mu \mathrm{L}$ of milk was spread on blood-esculin and MacConkey's agar and incubated aerobically for 24 to $48 \mathrm{~h}$ at $37^{\circ} \mathrm{C}$. Identification of bacteria was done by Gram staining, inspection of the colony morphology and biochemical testing. Catalase tests were performed to differentiate gram-positive cocci in catalase-positive or catalase-negative cocci. Staphylococci were identified as Staph. aureus or non-aureus staphylococci by colony morphology, hemolysis patterns, and DNase tests. Streptococci were differentiated in esculin-positive and esculin-negative streptococci (Streptococcus agalactiae and Streptococcus dysgalactiae). Streptococcus uberis 
was distinguished from other esculin-positive cocci by incubation in $\mathrm{NaCl} 6.5 \%$ medium and bile esculin agar. Christie, Atkins, Munch-Petersen tests were used to differentiate Strep. agalactiae and Strep. dysgalactiae. Gram-negative bacteria were identified by colony morphology, lactose fermentation on MacConkey agar, incubation in sulfide-indole-motility medium, and oxidase, triple sugar iron, citrate, and urease testing. The API 20 E system (bioMérieux, Craponne, France) was used if the previously mentioned tests failed to identify the gram-negative bacterium. Samples yielding 2 different bacterial species were grouped as a mixed culture, whereas samples yielding 3 or more different bacterial species were considered to be contaminated.

The lactation-level IRCM was calculated by dividing the number of quarter cases by the days at risk during the lactation within the study and expressed as cases per 10,000 cow-days at risk. Samples taken from the same cow within 2 wk from a previous case were not considered new cases and therefore excluded from the analysis (Barkema et al., 1998). The number of days at risk for each lactation was equal to the time between the start of the study or calving and the end of the study, culling date, or the next calving minus $14 \mathrm{~d}$ per case. Overall IRCM (all cases), as well as pathogen-specific IRCM (Staph. aureus, Strep. uberis, Strep. dysgalactiae, and Escherichia coli, specifically) were calculated (Verbeke et al., 2014).

Test-Day SCC and MY (Subset of Data, 32 Herds, 1,961 Cows). Composite milk SCC (cells per milliliter) and MY (kilograms of milk) at test-day per cow were available from DHI records of all herds participating in the DHI program ( $\mathrm{n}=32$ herds). Records between 14 and 285 DIM from cows with at least 2 measurements per parity were saved in a data set.

\section{CXCR1 Genotyping}

Genotype at SNP c.735C $>$ G and c.980A $>$ G was determined using a multiprobe PCR assay similar to the assay described by Van Poucke and colleagues (2005). The DNA was extracted from blood samples $(100 \mu \mathrm{L})$ using a proteinase $\mathrm{K}$ digestion method (Van Poucke et al., 2005). Three PCR primers and 4 dual-labeled allelespecific oligonucleotide probes were designed and synthesized by Sigma-Aldrich (St. Louis, MO). Sequences, melting temperature (calculated using OligoAnalyzer 3.1; Integrated DNA Technologies, Coralville, IA), and binding positions are presented in Table 1. Regions forming potential secondary structures or including repeat sequences were identified with Mfold (Zuker, 2003) and RepeatMasker (Smit et al., 2010), respectively, and avoided. The forward primer was designed to bind CXCR 1 specifically. Because of SNP $* 6 \mathrm{C}>\mathrm{A}$ (db SNP ss 974294528$), * 7 \mathrm{~A}>\mathrm{C}(\mathrm{db}$ SNP ss 974294529$)$, and *10C > T (db SNP ss 974294530), 2 reverse primers were used. Homology between $C X C R 1$ and $C X C R 2, C X C R 1$ SNP and binding positions of primers and probes are visualized in Figure 1. To amplify a region including both SNP specifically, a relatively large amplicon was multiplied (523 bp).

The PCR was performed in the CFX96 Touch RealTime PCR Detection System (Bio-Rad, Hercules, CA) with a $10-\mu \mathrm{L}$ PCR mix containing approximately 100 ng of genomic DNA, $1.0 \mu \mathrm{L}$ of $10 \times$ FastStart Taq DNA Polymerase Buffer (Roche Applied Science, Penzberg, Germany), dNTP Mix (0.2 mM each; 5 prime), $0.5 \mu M$ forward primer (Integrated DNA Technologies), $0.5 \mu M$ reverse primer 1 (Integrated DNA Technologies), 0.5 $\mu M$ reverse primer 2 (Integrated DNA Technologies), $0.6 \mu M$ C735-probe, $0.3 \mu M$ G735-probe, $0.4 \mu M$ A980probe, $0.2 \mu M$ G980-probe, and 0.5 U Taq DNA Polymerase (Roche Applied Science). The real-time PCR program consisted of an initiation step of $3.5 \mathrm{~min}$ at $95^{\circ} \mathrm{C}$, followed by 40 amplification cycles (denaturation for $30 \mathrm{~s}$ at $95^{\circ} \mathrm{C}$, annealing-elongation for $40 \mathrm{~s}$ at $60^{\circ} \mathrm{C}$, and detection of fluorescent signals generated by cleavage of the dual-labeled probes).

Quantification cycles ( $\mathrm{Cq}$ values) for each probe were analyzed using CFX Manager Software v3.1 (Bio-

Table 1. Primers and probes used in the real-time PCR assay for genotyping SNP $C X C R 1 \mathrm{c} .735 \mathrm{C}>\mathrm{G}$ and $C X C R 1 \mathrm{c} .980 \mathrm{~A}>\mathrm{G}$

\begin{tabular}{|c|c|c|c|c|c|}
\hline $\begin{array}{l}\text { Primer or } \\
\text { probe name }\end{array}$ & Sequence $\left(5^{\prime} \rightarrow 3^{\prime}\right)^{1}$ & $\begin{array}{l}\text { Length } \\
\text { (bp) }\end{array}$ & $\underset{\left({ }^{\circ} \mathrm{C}\right)}{\mathrm{Tm}^{2,3}}$ & $\begin{array}{l}\underset{\left({ }^{\circ} \mathrm{C}\right)}{\operatorname{armm}}{ }^{2,4}\end{array}$ & $\begin{array}{l}\text { Binding } \\
\text { position }\end{array}$ \\
\hline Forward primer & TCCGACCTAGTCTGCTA & 17 & 59.6 & $\mathrm{~N} / \mathrm{A}$ & c. $574 \rightarrow$ c. 590 \\
\hline Reverse primer 1 & CCGGTGTGGAGTCTC & 15 & 59.2 & $\mathrm{~N} / \mathrm{A}$ & c. $1082 \leftarrow * 13$ \\
\hline Reverse primer 2 & CG스GGTGAGTCTCAGA & 17 & 58.7 & 58.7 & c. $1079 \leftarrow * 12$ \\
\hline C735-probe & $H E \bar{X}$-CGGTGCTTGTGCCC-BHQ1 & 14 & 61.6 & 55.3 & c. $730 \leftarrow$ c. 743 \\
\hline G735-probe & FAM-CGGTGCTTE्CTGCCCC-BHQ1 & 15 & 64.0 & 54.2 & c. $729 \leftarrow$ c. 743 \\
\hline A980-probe & Cy5-CCATGATCTTGAGGAGTCC-BHQ2 & 19 & 60.3 & 56.5 & c. $970 \leftarrow$ c. 988 \\
\hline G980-probe & TexasRed-CCATGATCㅌTGAGGAGTCC-BHQ2 & 19 & 62.2 & 55.0 & c. $970 \leftarrow$ c. 988 \\
\hline
\end{tabular}

\footnotetext{
${ }^{1}$ Fluorescent labels and quenchers are in italic; SNP are underlined.

${ }^{2}$ Melting temperatures were calculated using OligoAnalyzer 3.1, Integrated DNA Technologies (Coralville, IA).

${ }^{3} \mathrm{Tm}=$ melting temperature when annealed to $C X C R 1$ for primers and to target variant for probes

${ }^{4}$ avTm $=$ melting temperature when annealed to $C X C R 2$ for primers and to allelic variant for probes.
} 
CXCR1

CXCR2

CXCR1

CXCR2

CXCR1

CXCR2

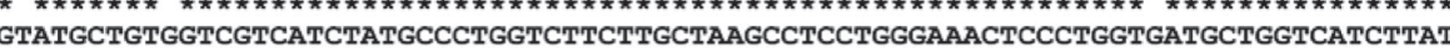
GCATGCTGTAGTCGTCATCTATGCCCTGGTCTTCTTGCTAAGCCTCCTGGGAAACTCCCTGGTAATGCTGGTCATCTTAT

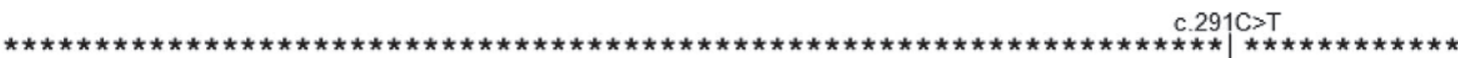
ACAGCCGGATTGGTCGCTCTGTCACTGATGTCTACCTGCTGAACCTGGCCATGGCTGACCTGCTCTTYGCCATGACCTTG ACAGCCGGATTGGTCGCTCTGTCACTGATGTCTACCTGCTGAACCTGGCCATGGCTGACCTGCTCTTCGCCATGACCTTG

CXCR1

CXCR2

CXCR1

CXCR2

CXCR1

CXCR2

CXCR1

CXCR2

CXCR1

CXCR2

CXCR1

CXCR2

CXCR1

CXCR2

CXCR1

CXCR2

CXCR1

CXCR2

CXCR1

CXCR2

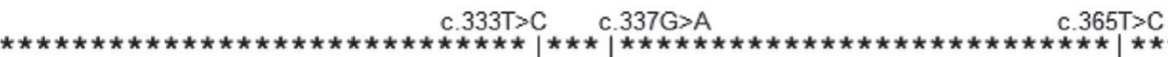

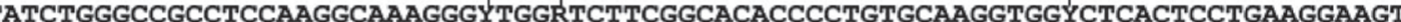
ССTATCTGGGCCGCCTCCAAGGCAAAGGGTTGGGTCTTCGGCACACCCCTGTGCAAGGTGGTCTCACTCCTGAAGGAAGT

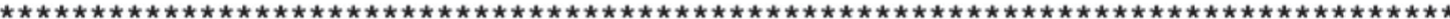
GAACTTCTACAGCGGTATTCTACTGCTGGCCTGCATCAGCATGGACCGCTACCTGGCCATTGTCCATGCCACACGCACGC GAACTTCTACAGCGGTATTCTACTGCTGGCCTGCATCAGCATGGACCGCTACCTGGCCATTGTCCATGCCACACGCACGC

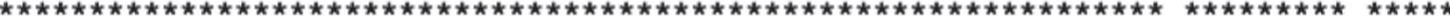
TGACCCAGAAGCGGCACTGGGTCAAGTTCATATGTTTAGGCATCTGGGCCCTGTCCGTGATCCTGGCCCTGCCCATCTTC TGACCCAGAAGCGGCACTGGGTCAAGTTCATATGTTTAGGCATCTGGGCCCTGTCCGTGATCCTAGCCCTGCCCGTCTTC

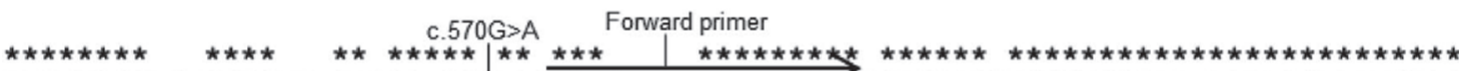
ATCTTCCGTGAGGCCTATCAACCACCRTACTCCGACCTAGTCTGCTACGAGGACCTGGGTGCCAATACAACGAAATGGCG ATCTTCCGCAGGGCCATCCACCCACCСTATTCCAGTGCAGTCTGCTATGAGGACATGGGTGCCAATACAACGAAATGGCG

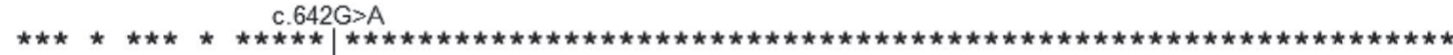
GATGATAATGCGTGTCCTRCCCCAGACCTTTGGCTTCCTCCTGCCCCTGCTGGTCATGCTGTTCTGCTACGGATTCACCC AATGGTGATGAGGGTCCTGCCCCAGACCTTTGGCTTCCTCCTGCCCCTGCTGGTCATGCTGTTCTGCTACGGATTCACCC

c. $735 \mathrm{C}>\mathrm{G} \mathrm{C735-probe}$

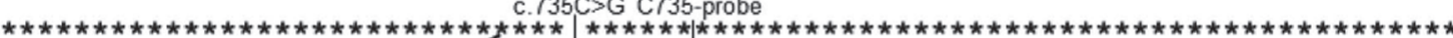
TGCGCACGCTGTTTTCAGCCCAAATG TGCGCACGCTGTTTTCAGCCCAAATGGGGCAGAAGCAC|CGGGCCATGCGGGTCATCTTTGCTGTCGTGCTCGTCTTCCTG G735-probe

c. $816 \mathrm{C}>\mathrm{A} \quad$ c. $819 \mathrm{G}>\mathrm{A}$

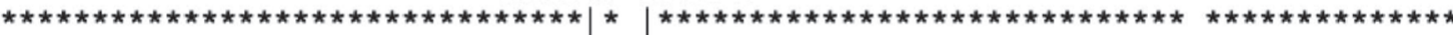
CTCTGCTGGCTGCCCTACAACCTGGTCCTGATMGCRGACACCCTCATGAGGGCCCATGTGATTGCTGAGACCTGTCAGCG CTCTGCTGGCTGCCCTACAACCTGGTCCTGATCGTGGACACCCTCATGAGGGCCCATGTGATTGCCGAGACCTGTCAGCG

BsrD1 recognistion sequence

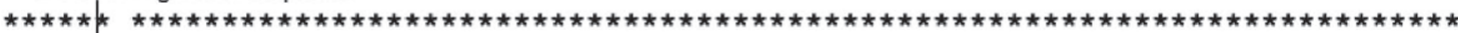
COGCAATGACATTGGCCGGGCCCTGGATGCCACCGAGATCCTGGGCTTCCTGCACAGCTGCCTCAACCCCCTCATCTACG CCGCAACGACATTGGCCGGGCCCTGGATGCCACCGAGATCCTGGGCTTCCTGCACAGCTGCCTCAACCCCCTCATCTACG

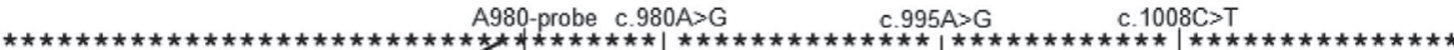

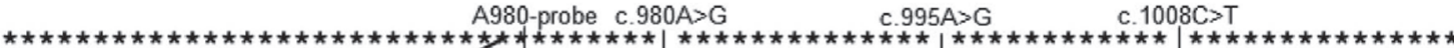

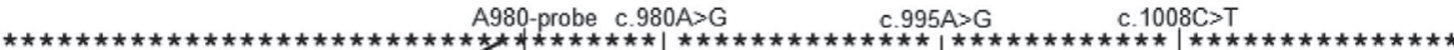
TCTTCATTGGCCAGAAGTTTCGCCACSACTCCTCARGATCATGGCCATCCRTGGCCTGATCAGYAAGGAGTTCTTGGCC TCTTCATTGGCCAGAAGTTTCGCCACGEACTCCTCAAGATCATGGCCATCCATGGCCTGATCAGCAAGGAGTTCTTGGCC G980-probe c. $1068 \mathrm{G}>\mathrm{A}$ ${ }^{*} 6 \mathrm{C}>\mathrm{A} \quad{ }^{*} 7 \mathrm{~A}>\mathrm{C} \quad{ }^{*} 10 \mathrm{C}>\mathrm{T}$ Reverse primer 1

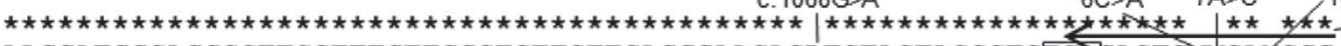
AAGGATGGCAGGCCTTCCTTTGTTGGCTCTTCTTCAGGGAACACRTCTACTACCCTCPGAGACTCMMCAYCGG AAGGATGGCAGGCCTTCCTTTGTTGGCTCTTCTTCAGGGAACACGTCTACTACCCTCTGAGACTCACCATCGG

CXCR1

CXCR2

Figure 1. The coding sequence and 13 bp downstream from the stop codon of bovine CXCR1, as detected by DNA sequencing (Verbeke et al., 2012), was aligned with bovine CXCR2 (AC_000159 region: 106913181... 106914285) using ClustalX2 (Larkin et al., 2007). The start codon, SNP in CXCR1, and stop codon are indicated. Binding positions of primers and probes used for CXCR1 genotyping (see Table 2) are marked with arrows. 
Rad). In each run, positive controls with genotype c.735CC980AA, c.735CG980AG, and c.735GG980GG and a no-template control were included to assign baseline cycles and threshold position, and check for PCR contamination. Potential unspecific amplification of $C X C R 2$ was analyzed by digesting a PCR amplicon with restriction enzyme BsrD1 (New England Biolabs, Ipswich, MA) according to the manufacturer's protocol. In silico analysis showed that BsrD1 cleaves the predicted CXCR 1 region, but not the homologous CXCR2 region (NM_001101285.1; Figure 1). The sample was run on ethidium bromide-stained agarose $(2 \%)$ gel (135 $\mathrm{V}, 40 \mathrm{~min}$ ). None of the original fragments was visible, indicating that no $C X C R 2$ was multiplied. To validate the genotyping method, 26 DNA samples genotyped by direct sequencing (Verbeke et al., 2012) were tested in a blind manner. At least 3 samples of genotype c.735CC980AA, c.735CC980AG, c.735CC980GG, c.735CG980AG, c.735CG980GG, and c.735GG980GG were included. Results were concordant for all 26 samples. Real-time amplification plots for all detected genotypes are presented in Figure 2.

\section{Statistical Analysis}

Deviations from Hardy-Weinberg equilibrium were analyzed using chi-squared goodness of fit tests. Chisquared values were calculated to analyze linkage disequilibrium between loci. The relative value of disequilibrium, d, was calculated as introduced by Kaplan and Weir (1992).

In all models, statistical significance was assessed at $P \leq 0.05$, whereas a $P$-value between 0.05 and 0.10 was considered as a tendency toward significance. Nonsignificant fixed effects, except genotype as a variable of main interest, were removed from the models. Genotypes c.735CC and c.980AA encoding the conserved AA p.245Glu and p.327Lys (Pighetti et al., 2012) were set as reference groups in the models with c.735C $>\mathrm{G}$ and c.980A $>\mathrm{G}$, respectively. Other genotypes were compared with the reference (2 independent post-hoc tests).

Clinical Mastitis. Associations between SNP c. $735 \mathrm{C}>\mathrm{G}$ and c. $980 \mathrm{~A}>\mathrm{G}$ and 5 different outcome variables - (1) overall IRCM, (2) Staph. aureus IRCM, (3) Strep. uberis IRCM, (4) Strep. dysgalactiae IRCM, and (5) E. coli IRCM - were determined in several models using multilevel Poisson regression (MlwiN 2.16, Centre for Multilevel Modeling, Bristol, UK). Herd and cow were added as a random effect to correct for clustering of cows within herds and lactations within cows. The models included the cow genotype (c.735C $>\mathrm{G}$ and c. $980 \mathrm{~A}>\mathrm{G}$ ) at the position of the polymorphism, parity $(1,2$, and $\geq 3$ ), season of calving (January-March,
April-June, July-September, and October-December), and the interaction between genotype and parity as categorical fixed effects and the natural logarithm of the number of days at risk as an offset variable (Barkema et al., 1999). To avoid nonconvergence of the statistical models, records on rare genotypes (c.980AA) were omitted in the pathogen-specific models. In latter models, c.980AG was set as reference. Results are presented as rate ratio (RR) with $95 \%$ CI.

Test-Day SCC and MY. Associations between SNP c.735C $>\mathrm{G}$ and c.980A $>\mathrm{G}$ (predictor variables of main interest) and test-day SCC and MY (separate outcome variables) were determined using 2 mixed regression models per outcome variable with herd, cow, and lactation as random effects to correct for clustering of cows within herds, lactations within cows, and multiple observations per lactation, respectively (MlwiN 2.16). A natural logarithmic transformation of SCC (LnSCC) was performed to obtain a normalized distribution. The models included DIM and the quadratic term for DIM as continuous fixed effects and the cow genotype (c.735C $>\mathrm{G}$ and c.980A $>\mathrm{G}$ ) at the position of the polymorphism, parity $(1,2$, and $\geq 3)$, season of calving (January-March, April-June, July-September, and October-December), season of the test day (January-March, April-June, July-September, and October-December), and the interaction between genotype and parity as categorical fixed effects.

\section{RESULTS}

\section{Phenotypic Data}

The average herd size was 60 lactating cows (range 16-240). All producers milked Holstein-Friesian cows. During the survey, participating herds had an average bulk milk SCC of 236,000 cells/mL (range 85,000 453,000 cells $/ \mathrm{mL}$ ).

In total, $685 \mathrm{CM}$ cases from 534 cows were sampled by the producers. During the survey, 421, 94, 18, 3, and 2 cows suffered from $1,2,3,4$, and 5 cases, respectively. Seventy-nine percent $(\mathrm{n}=538)$ of the samples were culture-positive, including $10 \%$ of contaminated samples $(\mathrm{n}=69)$. Streptococcus uberis was the most frequently isolated pathogen $(\mathrm{n}=121,18 \%$ of all cases), followed by E. coli $(\mathrm{n}=98,14 \%)$, Staph. aureus $(\mathrm{n}=55,8 \%)$, and Strep. dysgalactiae ( $\mathrm{n}=51,7 \%)$. Two different pathogens were isolated in $35 \mathrm{CM}$ samples (5\%). Nonaureus staphylococci $(\mathrm{n}=32,5 \%)$, Corynebacterium bovis $(\mathrm{n}=17,2 \%)$, yeast $(\mathrm{n}=14,2 \%)$, Prototheca spp. ( $\mathrm{n}=12,2 \%)$, other esculine-positive cocci besides Strep. uberis $(\mathrm{n}=9,1 \%)$, Klebsiella spp. $(\mathrm{n}=7,1 \%)$, Trueperella pyogenes $(\mathrm{n}=5,1 \%)$, Bacillus spp. $(\mathrm{n}=$ $3,<1 \%)$, Pasteurella spp. $(\mathrm{n}=3,<1 \%)$, Streptococcus 

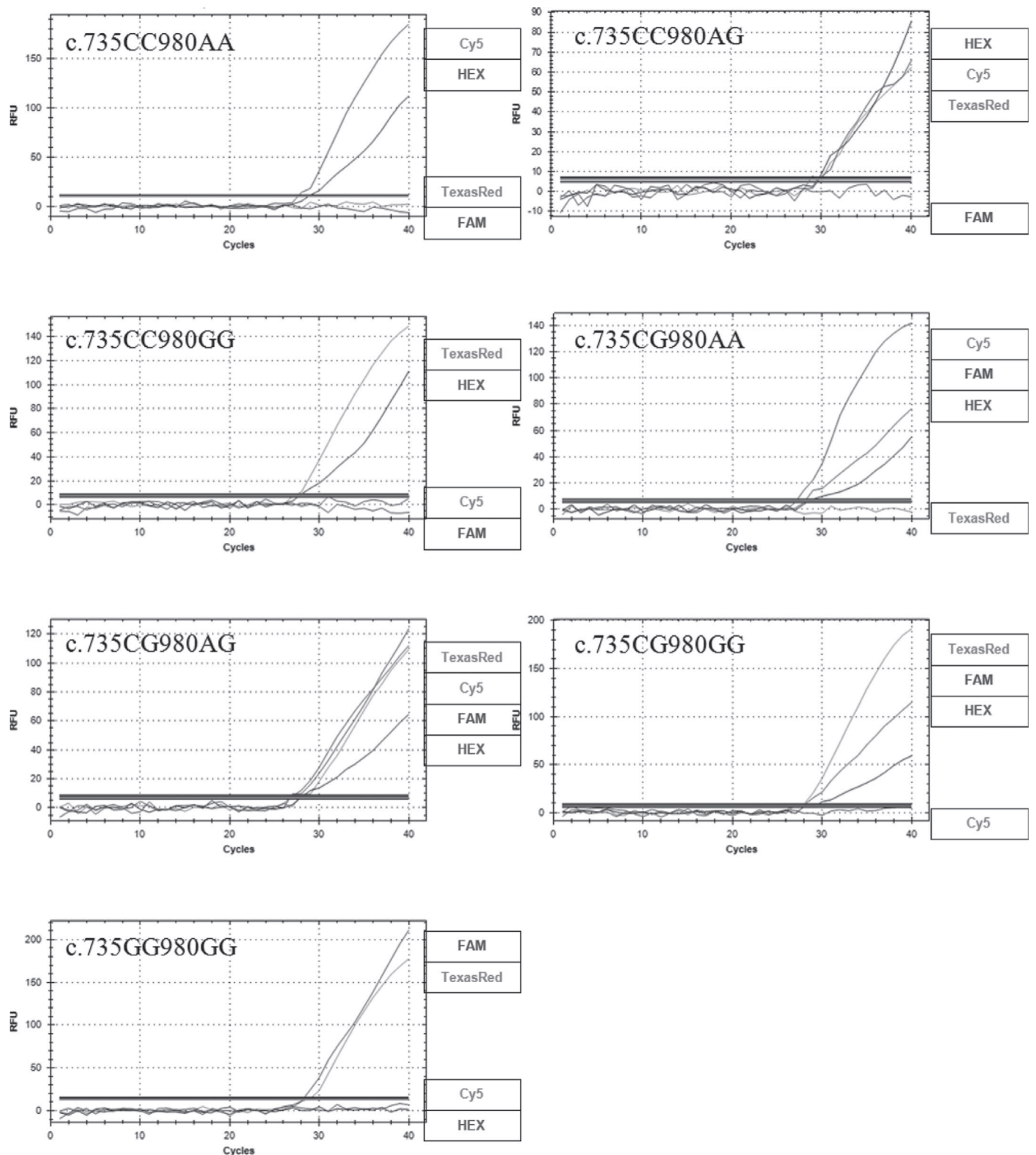

Figure 2. Amplification plots obtained with the fluorescent multiprobe PCR assay for bovine $C X C R 1$ genotyping of 7 cows with different genotype at SNP CXCR1c.735C > G or $C X C R 1$ c.980A $>$ G. Alleles c.735C, c.735G, c.980A, and c.980G were detected using probes labeled with fluorescent labels HEX, FAM, Cy5, and TexasRed, respectively. Genotype c.735GG980AA and c.735GG980AG were not detected in the study population. RFU = relative fluorescence unit. 
canis $(\mathrm{n}=3,<1 \%)$, Pseudomonas aeruginosa $(\mathrm{n}=3$, $<1 \%)$, Strep. agalactiae ( $\mathrm{n}=2,<1 \%)$, Serratia spp. (n $=2,<1 \%)$, and molds $(\mathrm{n}=1,<1 \%)$ were isolated in the remaining samples. Overall, Staph. aureus, Strep. uberis, Strep. dysgalactiae, and E. coli IRCM was calculated at $7.1,0.5,1.3,0.5$, and 1.1 quarter cases per 10,000 cowdays at risk, respectively. In herds participating in the DHI program, genotyped cows had a geometric mean SCC of 79,000 cells/mL (range: $2,000-9,590,000$ ) and an average MY of $27.8 \mathrm{~kg}$ (range: 1.9-63.5) at test day.

\section{Genotypic Data}

The sire and dam of 957 (31\%) and 1,964 (63\%) cows, respectively, were available from DHI records. Among these cows, 460 different sires and 1,951 different dams were noted, indicating that they were not closely related to each other.

All cows were genotyped using the multiprobe PCR assay. Frequencies of genotype c.735CC, c.735CG, and c.735GG were 25,48 , and $27 \%$, respectively, in the total population. Frequencies of genotype c.980AA, c. $980 \mathrm{AG}$, and c.980GG were 5,34 , and $61 \%$, respectively, in the total population. Frequencies of c. $735 \mathrm{C}>\mathrm{G}$ and c.980A $>$ G were not significantly different in the subpopulation of cows with DHI records compared with the total population $\left[\mathrm{P}\left(\chi_{2 d f}^{2}>0.45\right)=0.80\right.$ and $\mathrm{P}\left(\chi_{2 d f}^{2}>0.95\right)=0.62$, respectively]. Both SNP were in Hardy-Weinberg equilibrium $(P>0.05)$. In total, 7 combined genotypes were detected: c.735CC980AA (5\%), c.735CC980AG (12\%), c.735CC980GG (8\%), c.735CG980AA $(<1 \%)$, c.735CG980AG (22\%), c.735CG980GG (26\%), and c.735GG980GG (27\%). Combined genotypes c.73GG980AA and c.735GG980AG were not observed in the study population. The SNP were in strong linkage disequilibrium $(P<0.05, \mathrm{~d}=$ $0.65)$.

\section{Associations with Udder Health and MY}

Descriptive statistics on pathogen-specific IRCM, LnSCC, and MY by SNP c.735C $>$ G and c.980A $>$ G are given in Table 2.

Incidence Rate of $\boldsymbol{C M}$. Season of calving was not associated with (pathogen-specific) IRCM and was therefore removed from all IRCM models. Overall, Strep. uberis, Strep. dysgalactiae, and E. coli IRCM were significantly associated with parity $(P<0.05)$, but not with SNP c.735C $>$ G, c.980A $>$ G or the interaction between genotype and parity (Table 3). Results were different for Staph. aureus IRCM. In the model with c.735C $>$ G, the interaction between c.735C $>\mathrm{G}$ and parity was not significant. Parity was significant
$(P<0.01)$ and genotype tended to be significant $(P=$ 0.08 ). Cows with genotype c.735GG had, on average, a lower Staph. aureus IRCM compared with cows with genotype c.735CC $(\mathrm{RR}=0.35,95 \% \mathrm{CI}=0.14-0.90$; Table 3). In the model with c.980A $>\mathrm{G}$, the interaction between genotype and parity was significant $(P<$ $0.05)$. Heifers with genotype c.980GG had on average a lower Staph. aureus IRCM compared with heifers with genotype c.980AG $(\mathrm{RR}=0.15,95 \% \mathrm{CI}=0.04-0.56)$. The association between c.980A $>$ G and Staph. aureus IRCM was less pronounced in cows with parity 2 and $\geq 3$ (Table 3 ).

$\boldsymbol{S C C}$. Season of calving, season of test day, $\mathrm{DIM}^{2}$, and the interaction between genotype and parity were not associated with LnSCC and were therefore removed from both LnSCC models. Test-day LnSCC was significantly associated with parity $(P<0.01)$ and DIM $(P<$ 0.01 ), but not with genotype (Table 4 ).

$\boldsymbol{M Y}$. The interaction between genotype and parity was not associated with MY and was therefore removed from both MY models. Test-day MY was significantly associated with parity, season of calving, season of test-day, DIM, and $\operatorname{DIM}^{2}(P<0.01)$. Milk yield was associated with SNP c.735C $>\mathrm{G}(P<0.05)$, but not with SNP c.980A $>\mathrm{G}(P=0.13)$. Cows with genotype c.735CG and genotype c.735GG produced, on average, 0.30 (SE 0.27) and 0.81 (SE 0.31) more kilograms of milk per day compared with c.735CC cows (Table 4).

\section{DISCUSSION}

Several research groups studied associations between SNP in CXCR1 and udder health (Youngerman et al., 2004; Leyva-Baca et al., 2008b; Goertz et al., 2009; Beecher et al., 2010; Galvão et al., 2011; Verbeke et al., 2012). However, we were the first to study pathogenspecific data in a relative large population from multiple commercial dairy herds. The 50 study herds were randomly selected. No inclusion criteria were applied in our study, underlining the external validity of our results. A downside of this selection procedure was the lack of DHI records and pedigree information in a large number of herds. Consequently, we could not study test-day MY and LnSCC of all animals, nor account for additive polygenic effects in the statistic models.

Different methods were used to genotype animals in previous studies. Sequencing allows detection of new SNP (Youngerman et al., 2004; Verbeke et al., 2012), but is relatively expensive and time consuming. The PCR-RFLP assay used by Goertz et al. (2009), Beecher et al. (2010), and Galvão et al. (2011) is cheaper and contains only 4 steps (DNA extraction, PCR, restriction enzyme digestion, and gel electrophoresis). To further reduce the time required per sample, we designed a 
Table 2. Descriptive statistics of pathogen-specific incidence rate of clinical mastitis (IRCM; cases/10.000 cow-days at risk) and test-day LnSCC ${ }^{1}$ and milk yield between 14 and 285 DIM by $C X C R 1$ genotype and parity

c.735C $>$ G genotype

-

c. $980 \mathrm{~A}>\mathrm{G}$ genotype

Outcome variable

\begin{tabular}{rrrr} 
Parity & CC & CG & GG \\
\hline 50 & 50 & 50 & \\
772 & 1,502 & 832 & 1
\end{tabular}

Herds with CM data

Cows with CM data
Lactations with CM data

Total IRCM (cases)

Staphylococcus aureus IRCM (cases)

Streptococcus uberis IRCM (cases)

Streptococcus dysgalactiae IRCM (cases)

Escherichia coli IRCM (cases)

Herds with DHI records ${ }^{2}$

Cows with DHI records

Lactations with DHI records

Test-days with DHI records

$\operatorname{LnSCC}( \pm$ SEM $)$

$\operatorname{Milk~yield}^{3}( \pm$ SEM)

$\begin{array}{ll}1 & 363 \\ 2 & 348 \\ 3 & 465 \\ 1 & \\ 2 & \end{array}$

348

659

601

$4.0(36)$

$6.4(43)$

931

10.9 (93)

4.1 (69)

390

348

0.4 (4)

$6.2(80)$

508

$0.7(5)$

1.1 (9)

$0.7(6)$

$0.7(5)$
$1.8(15)$

$1.8(15)$
$0.2(2)$

$0.9(6)$

$0.6(5)$

$0.9(8)$

$0.9(6)$

$11.0(192)$

$3.5(34)$

$0.6(10)$

$9.0(86)$

$0.4(5)$

$0.1(1)$

0.2 (1)

$0.9(15)$

$0.7(11)$

$0.5(5)$

$0.7(9)$

$2.3(39)$

$0.9(9)$

$1.1(7)$
$2.1(20)$

$0.2(4)$
$0.6(8)$

$0.6(8)$
$1.1(19)$

0.4 (4)

$0.2(1)$

$0.2(2)$

0.6 (6)

$1.2(16)$

$1.4(9)$

32
474

32
474
181
163

$\begin{array}{rr}2 & 163 \\ \geq 3 & 184\end{array}$

184
976

976
896

$1.7(28)$

32
966
371
326

371
326

417

1,902

1,444

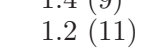

32

521

198

168

236

1,017

$4.13(0.04) \quad 4.08(0.03) \quad 4.12(0.04)$

$4.47(0.05) \quad 4.41(0.03) \quad 4.32(0.04)$

$4.80(0.05) \quad 4.75(0.03)$

$24.4(0.2)$

$24.7(0.1)$

$4.65(0.04)$

$28.6(0.3) \quad 30.9(0.2)$

$29.1(0.3)$

$31.2(0.3)$

\begin{tabular}{|c|c|c|c|}
\hline $\mathrm{AA}$ & AG & GG & Total \\
\hline 41 & 50 & 50 & 50 \\
\hline 149 & 1,053 & 1,904 & 3,106 \\
\hline 62 & 511 & 881 & 1,454 \\
\hline 64 & 453 & 838 & 1,355 \\
\hline 103 & 622 & 1,179 & 1,904 \\
\hline $3.8(6)$ & $4.3(54)$ & $3.7(79)$ & $3.9(139)$ \\
\hline $5.0(6)$ & $5.6(48)$ & $7.3(121)$ & $6.7(175)$ \\
\hline $7.7(15)$ & $12.0(129)$ & $10.0(227)$ & $10.6(371)$ \\
\hline $0.0(0)$ & $1.0(12)$ & $0.1(3)$ & $0.4(15)$ \\
\hline $0.8(1)$ & $0.5(4)$ & $0.4(6)$ & $0.4(11)$ \\
\hline $0.0(0)$ & $0.7(8)$ & $1.0(21)$ & $0.8(29)$ \\
\hline $0.0(0)$ & $0.6(8)$ & 0.9 (18) & $0.7(26)$ \\
\hline $0.8(1)$ & $0.5(4)$ & $1.0(16)$ & $0.8(21)$ \\
\hline $2.6(5)$ & $2.1(24)$ & $2.1(45)$ & $2.1(74)$ \\
\hline $0.0(0)$ & $0.2(3)$ & $0.3(7)$ & $0.3(10)$ \\
\hline $1.7(2)$ & $0.6(5)$ & $0.5(8)$ & $0.6(15)$ \\
\hline $0.0(0)$ & $0.9(10)$ & $0.7(16)$ & $0.7(26)$ \\
\hline $0.0(0)$ & $0.6(8)$ & $0.6(13)$ & $0.6(21)$ \\
\hline $0.0(0)$ & $1.4(12)$ & $1.2(19)$ & $1.2(31)$ \\
\hline $2.0(4)$ & $2.0(22)$ & $1.4(30)$ & $1.6(56)$ \\
\hline 28 & 32 & 32 & 32 \\
\hline 93 & 691 & 1,177 & 1,961 \\
\hline 31 & 291 & 428 & 750 \\
\hline 35 & 215 & 407 & 657 \\
\hline 43 & 294 & 521 & 858 \\
\hline 163 & 1,506 & 2,226 & 3,895 \\
\hline 145 & 941 & 1,827 & 2,913 \\
\hline 200 & 1,296 & 2,222 & 3,718 \\
\hline $4.14(0.09)$ & $4.14(0.03)$ & $4.08(0.02)$ & $4.10(0.02)$ \\
\hline $4.21(0.10)$ & $4.43(0.04)$ & $4.40(0.03)$ & $4.40(0.02)$ \\
\hline $4.74(0.10)$ & $4.80(0.04)$ & $4.70(0.03)$ & $4.74(0.02)$ \\
\hline $23.8(0.4)$ & $24.8(0.2)$ & $25.0(0.1)$ & $24.8(0.1)$ \\
\hline $27.7(0.7)$ & $27.9(0.3)$ & $28.6(0.2)$ & $28.4(0.2)$ \\
\hline $30.4(0.7)$ & $30.6(0.3)$ & $30.8(0.2)$ & $30.7(0.2)$ \\
\hline
\end{tabular}

${ }^{1}$ Natural logarithmic transformed test-day composite SCC (LnSCC).

${ }^{2}$ Thirty-two out of 50 study herds participated in a DHI program.

${ }^{3}$ In kilograms of milk per day. 
Table 3. Multilevel Poisson regression models describing the associations between the pathogen-specific incidence rate of clinical mastitis (IRCM) and SNP CXCR1c.735C $>$ G and CXCR1c. $980 \mathrm{~A}>\mathrm{G}$, respectively

\begin{tabular}{|c|c|c|c|c|c|c|c|c|c|c|c|c|c|c|}
\hline IRCM & $\begin{array}{l}\text { Independent } \\
\text { variable }\end{array}$ & Subset & $\beta^{1}$ & SE & $\mathrm{RR}^{2}$ & $95 \%$ CI RR ${ }^{3}$ & $P$-value ${ }^{4}$ & $\begin{array}{l}\text { Independent } \\
\text { variable }\end{array}$ & Subset & $\beta^{1}$ & $\mathrm{SE}$ & $\mathrm{RR}^{2}$ & $95 \%$ CI RR ${ }^{3}$ & $P$-value ${ }^{4}$ \\
\hline \multirow[t]{7}{*}{ Overall } & \multirow[t]{3}{*}{$\begin{array}{l}\text { Intercept } \\
\text { c. } 735 \mathrm{C}>\mathrm{G}^{5}\end{array}$} & $\mathrm{CC}$ & -7.87 & \multicolumn{3}{|c|}{$\begin{array}{l}0.16 \\
\quad \text { Reference }\end{array}$} & \multirow[t]{3}{*}{0.73} & \multirow[t]{3}{*}{$\begin{array}{l}\text { Intercept } \\
\text { c. } 980 A>G^{6}\end{array}$} & AA & -8.17 & \multicolumn{3}{|c|}{$\begin{array}{l}0.26 \\
\text { Reference }\end{array}$} & \multirow[t]{3}{*}{0.29} \\
\hline & & CG & 0.04 & 0.11 & 1.04 & $0.84-1.28$ & & & $\mathrm{AG}$ & 0.36 & 0.23 & 1.43 & $0.91-2.27$ & \\
\hline & & GG & -0.05 & 0.13 & 0.95 & $0.75-1.22$ & & & GG & 0.30 & 0.23 & 1.35 & $0.86-2.10$ & \\
\hline & \multirow[t]{3}{*}{ Parity } & 1 & \multicolumn{4}{|c|}{ Reference } & \multirow[t]{3}{*}{$<0.01$} & \multirow[t]{3}{*}{ Parity } & 1 & & \multicolumn{2}{|c|}{ Reference } & & \multirow[t]{3}{*}{$<0.01$} \\
\hline & & 2 & 0.60 & 0.12 & 1.83 & $1.44-2.32$ & & & 2 & 0.61 & 0.12 & 1.83 & $1.45-2.33$ & \\
\hline & & $\geq 3$ & 1.05 & 0.11 & 2.86 & $2.30-3.56$ & & & $\geq 3$ & 1.06 & 0.11 & 2.88 & $2.32-3.58$ & \\
\hline & Interaction & & & & & & NS & \multirow{4}{*}{$\begin{array}{l}\text { Interaction } \\
\text { Intercept } \\
\text { c. } 980 A>G^{6}\end{array}$} & & & & & & \multirow[t]{2}{*}{ NS } \\
\hline \multirow[t]{8}{*}{ Staphylococcus aureus } & \multirow{3}{*}{$\begin{array}{l}\text { Intercept } \\
\text { c. } 735 \mathrm{C}>\mathrm{G}^{5}\end{array}$} & $\mathrm{CC}$ & -9.83 & \multicolumn{2}{|c|}{ Reference } & & \multirow{3}{*}{0.08} & & $\mathrm{AA}$ & -9.30 & 0.34 & & & \\
\hline & & CG & -0.16 & 0.34 & 0.85 & $0.44-1.65$ & & & $\mathrm{AG}$ & & & ference & & \\
\hline & & GG & -1.05 & 0.48 & 0.35 & $0.14-0.90$ & & & GG & -1.91 & 0.68 & 0.15 & $0.04-0.56$ & \\
\hline & Parity & 1 & & & ference & & $<0.05$ & Parity & 1 & & & ference & & $<0.05$ \\
\hline & & 2 & 0.01 & 0.42 & 1.00 & $0.44-1.65$ & & & 2 & -0.67 & 0.61 & 0.51 & $0.16-1.69$ & \\
\hline & & $\geq 3$ & 0.73 & 0.35 & 2.08 & $1.05-4.12$ & & & $\geq 3$ & -0.26 & 0.51 & 0.77 & $0.29-2.07$ & \\
\hline & Interaction & & & & & & NS & Interaction & $\overline{\mathrm{G}} \mathrm{G}^{*} 2$ & 1.63 & 0.95 & 5.08 & $0.79-32.82$ & $<0.05$ \\
\hline & & & & & & & & & $\mathrm{GG}^{*} \geq 3$ & 2.23 & 0.82 & 9.29 & $1.87-46.26$ & \\
\hline Streptococcus uberis & Intercept & & -9.55 & 0.37 & & & & Intercept & & -9.44 & 0.28 & & & \\
\hline & c. $735 \mathrm{C}>\mathrm{G}^{5}$ & $\begin{array}{l}\text { CC } \\
\text { CG }\end{array}$ & 0.20 & $0.23^{\mathrm{R}}$ & $\begin{array}{l}\text { ference } \\
1.22\end{array}$ & $0.78-1.89$ & 0.59 & c. $980 \mathrm{~A}>\mathrm{G}^{6}$ & $\begin{array}{l}\text { AA } \\
\text { AG }\end{array}$ & & & ference & & 0.49 \\
\hline & & GG & 0.25 & 0.25 & 1.28 & $0.78-2.09$ & & & GG & 0.13 & 0.19 & 1.14 & $0.78-1.66$ & \\
\hline & Parity & 1 & & & & & $<0.01$ & Parity & 1 & & & ference & & $<0.01$ \\
\hline & & 2 & 0.07 & 0.28 & 1.07 & $0.62-1.85$ & & & 2 & 0.03 & 0.28 & 1.03 & $0.59-1.79$ & \\
\hline & & $\geq 3$ & 1.03 & 0.22 & 2.80 & $1.83-4.29$ & & & $\geq 3$ & 1.01 & 0.22 & 2.75 & $1.78-4.23$ & \\
\hline & Interaction & & & & & & NS & Interaction & & & & & & NS \\
\hline Streptococcus dysgalactiae & $\begin{array}{l}\text { Intercept } \\
\text { c. } 735 \mathrm{C}>\mathrm{G}^{5}\end{array}$ & $\mathrm{CC}$ & -10.45 & $\begin{array}{r}0.42 \\
\mathrm{R}\end{array}$ & ference & & 0.13 & $\begin{array}{l}\text { Intercept } \\
\text { c. } 980 \mathrm{~A}>\mathrm{G}^{6}\end{array}$ & AA & -10.39 & 0.39 & & & 0.77 \\
\hline & & CG & 0.20 & 0.36 & 1.22 & $0.61-2.44$ & & & $\mathrm{AG}$ & & & ference & & \\
\hline & & GG & -0.68 & 0.49 & 0.51 & $0.19-1.33$ & & & GG & -0.09 & 0.32 & 0.91 & $0.49-1.71$ & \\
\hline & Parity & 1 & & & ference & & $<0.05$ & Parity & 1 & & & ference & & $<0.05$ \\
\hline & & 2 & 0.69 & 0.42 & 1.99 & $0.87-4.57$ & & & 2 & 0.57 & 0.44 & 1.78 & $0.75-4.19$ & \\
\hline & & $\geq 3$ & 0.96 & 0.39 & 2.62 & $1.22-5.63$ & & & $\geq 3$ & 1.00 & 0.39 & 2.72 & $1.26-5.88$ & \\
\hline & Interaction & & & & & & NS & Interaction & & & & & & NS \\
\hline Escherichia coli & Intercept & $\mathrm{CC}$ & -9.63 & $\begin{array}{r}0.34 \\
\mathrm{R}\end{array}$ & ference & & & Intercept & & -9.56 & 0.32 & & & \\
\hline & C.150 $>0$ & CG & -0.20 & 0.27 & 0.82 & $0.48-1.39$ & 0.73 & c. $.980 \mathrm{~A}>\mathrm{G}^{\circ}$ & $\begin{array}{l}\text { AA } \\
\text { AG }\end{array}$ & & & ference & & 0.24 \\
\hline & & GG & -0.20 & 0.31 & 0.82 & $0.45-1.51$ & & & GG & -0.27 & 0.23 & 0.76 & $0.48-1.21$ & \\
\hline & Parity & 1 & & & ference & & & Parity & 1 & & $\operatorname{Re}$ & ference & & $<0.01$ \\
\hline & & 2 & 0.79 & 0.31 & 2.21 & $1.22-4.02$ & & & 2 & 0.79 & 0.30 & 2.20 & $1.21-3.99$ & \\
\hline & & $\geq 3$ & 1.03 & 0.29 & 2.81 & $1.60-4.96$ & & & $\geq 3$ & 0.97 & 0.29 & 2.64 & $1.49-4.65$ & \\
\hline & Interaction & & & & & & NS & Interaction & & & & & & NS \\
\hline${ }^{1}$ Regression coefficient. & & & & & & & & & & & & & & \\
\hline & & & & & & & & & & & & & & \\
\hline${ }^{3} 95 \%$ confidence interval o & & & & & & & & & & & & & & \\
\hline${ }^{4}$ Overall $P$-value of the fixe & effect. & & & & & & & & & & & & & \\
\hline${ }^{5}$ Genotype at SNP $C X C R$ & $35 \mathrm{C}>\mathrm{G}$ & & & & & & & & & & & & & \\
\hline${ }^{6}$ Genotype at SNP $C X C R$ & $980 \mathrm{~A}>$ G. Cor & & pe $c$. & 1 & re excl & luded fro & nalys & 11 & nce. & & & & & \\
\hline
\end{tabular}


Table 4. Mixed regression models describing the associations between test-day $\operatorname{LnSCC}^{1}$ and milk yield between 14 and 285 DIM and SNP $C X C R 1 \mathrm{c} .735 \mathrm{C}>\mathrm{G}$ and $C X C R 1 \mathrm{c} .980 \mathrm{~A}>\mathrm{G}$, respectively

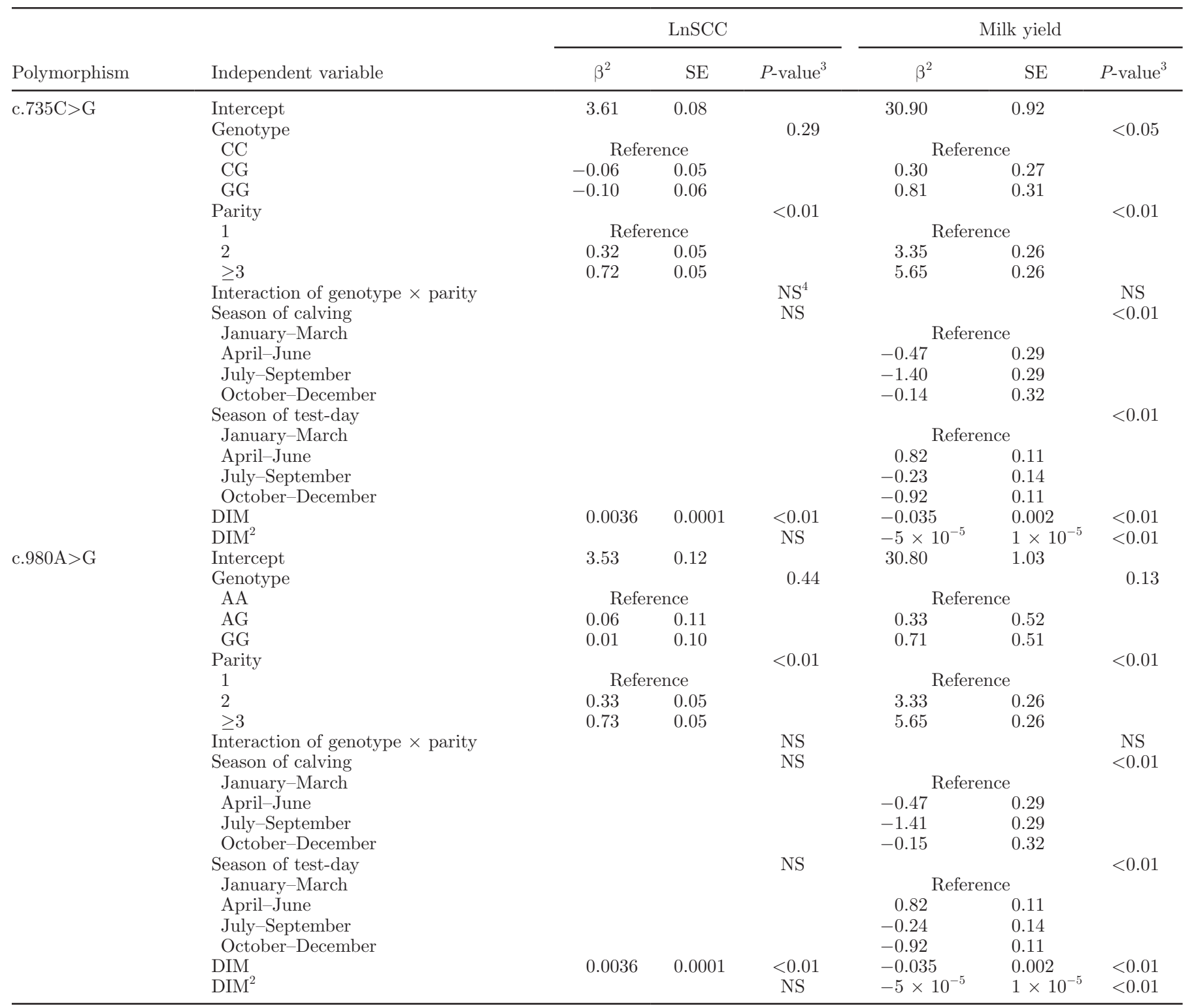

${ }^{1}$ Natural logarithmic transformed test-day composite SCC (LnSCC).

${ }^{2}$ Regression coefficient.

${ }^{3}$ Overall $P$-value of the fixed effect.

${ }^{4}$ Nonsignificant fixed effects except genotype were removed from the models.

fluorescent multiprobe PCR assay allowing us to genotype SNP c.735C $>$ G and c.980A $>$ G simultaneously in only 2 steps (DNA extraction and PCR). Using this assay, we could process the relative large number of samples cost and time effectively. Although the use of small amplicons (75-150 bp) is recommended (Livak, 1999), we used a relatively large amplicon to be able to genotype the SNP simultaneously. Purification of DNA and usage of special qPCR mixes generally result in lower Cq-values and higher RFU (relative fluorescence units) values (own observations) but was not required in our assay, which reduced the cost per sample. Comparison with sequence data demonstrated that results were reliable and repeatable. The assay can be used in further research or in breeding programs.

When studying associations between gene polymorphisms and mastitis resistance, different udder health parameters can be measured (Pighetti and Elliott, 2011). By monitoring clinical signs, CM incidence can be estimated directly. In the Nordic countries Denmark, 
Finland, Norway, and Sweden, disease-recording systems provide CM data on the majority of dairy herds (Wolff et al., 2012). In Belgium and other countries, CM data are not available on a larger scale. Yet, conducting our study on the same herds as a study estimating the IRCM in Flanders (Verbeke et al., 2014) enabled us to analyze associations between SNP in CXCR1 and IRCM in a relatively large population. However, we could not confirm the overall higher IRCM in c.735GG cows compared with c.735CG and CC cows observed by Galvão et al. (2011). Because different mastitis pathogens elicit different immune responses (Bannerman et al., 2004; Schukken et al., 2011), we also analyzed associations with pathogen-specific IRCM. This allowed us to detect a lower Staph. aureus IRCM in c.735GG compared with c.735CC cows. Additionally, genotype c.980GG was associated with lower Staph. aureus IRCM in heifers but not in multiparous cows. The interaction between SNP c.980A $>\mathrm{G}$ and parity could be explained by differences in innate immunity between heifers and multiparous cows. Phagocytosis and killing of Staph. aureus by milk PMNL was shown to be higher in heifers compared with multiparous cows (Mehrzad et al., 2009). Although Staph. aureus IMI elicits little to no IL-8 response (Bannerman, 2009), SNP in the gene encoding its receptor were associated with Staph. aureus IRCM. However, we should mention that the number of Staph. aureus cases was limited in our study and that we could not account for additive polygenic effects in the statistic models. The association does not prove causality and needs further substantiation (e.g., through conducting an experimental challenge study in which several cows per genotype are infected with Staph. aureus). Polymorphisms linked with SNP c. $735 \mathrm{C}>\mathrm{G}$ and c.980A $>\mathrm{G}$ might cause differential immune responses following Staph. aureus IMI and explain the differences in Staph. aureus IRCM, and could be pictured in such an experiment. Additionally, it could elucidate why genotype c.980AG was associated with a lower Staph. aureus IRCM in our study yet with a higher likelihood of IMI by major pathogens in a previous study (Verbeke et al., 2012). Hypothetically, heifers with genotype c.980AG are more likely to develop clinical signs in cases of Staph. aureus IMI without being more susceptible to the pathogen. Considering Staph. aureus is a major cause of CM (Olde Riekerink et al., 2008; Keane et al., 2013; Oliveira et al., 2013) associated with considerable milk losses worldwide (Hertl et al., 2014), more research on this topic is warranted and justified.

Besides (pathogen-specific) IRCM, we also studied SCC at test day. Similar to Goertz et al. (2009), Galvão et al. (2011), and Verbeke et al. (2012), no associations between SCC and SNP in CXCR1 were detected.
This does not necessarily indicate that the SNP are not associated with incidence of SM, as SCC is merely an indirect test for subclinical mastitis that does not give information on the pathogens associated with the SCC elevations. Yet, using culture data, c.735C $>\mathrm{G}$ was found to be associated with overall incidence of SM (Youngerman et al., 2004), whereas c.980A $>$ G was found to be associated with the prevalence of SM caused by major pathogens in early lactating heifers (Verbeke et al., 2012). Culture data on a large number of SM cases were not collected in our study, but would have allowed to test pathogen-specific associations between SNP in $C X C R 1$ and SM incidence as well.

Marker-assisted selection against mastitis is a noble goal, but would receive little attention if it would decrease the genetic merit for production (Detilleux, 2009). Unfavorable genetic correlations between CM and MY traits have been described (Koivula et al., 2004). Therefore, we also tested associations between SNP c. $735 \mathrm{C}>\mathrm{G}$ and c.980A $>\mathrm{G}$ and MY. Besides a lower Staph. aureus IRCM, c.735GG had higher MY compared with c.735CC cows, contradicting findings by Galvão et al. (2011). Whether the lower Staph. aureus IRCM partly explains the higher MY is hard to test because the traits were recorded in somewhat different populations.

As mentioned in the introduction, functional effects of CXCR1 SNP have yet to be analyzed. As suggested by Pighetti et al. (2012), AA change p.His245Glu caused by c.735C $>\mathrm{G}$ could affect G-protein binding and signal transduction, whereas AA change p.Lys327Arg caused by c. $980 \mathrm{~A}>\mathrm{G}$ could interfere with adaptin- 2 binding and receptor internalization. In silico analysis showed an important role of the $\mathrm{N}$ terminus of CXCR1 in the first steps of binding IL-8 (Liou et al., 2014). Hence, AA changes p.Ile13Tyr and p.Gly23Glu in this region caused by SNP c.37A $>$ T, c. $38 \mathrm{~T}>\mathrm{A}$, and c. $68 \mathrm{G}>\mathrm{A}$ being in strong linkage disequilibrium with c.735C $>\mathrm{G}$ could alter ligand binding. Latter and other processes could affect receptor functionality and therefore mastitis resistance or susceptibility.

\section{CONCLUSIONS}

A fluorescent multiprobe PCR assay was designed, validated, and used to genotype $C X C R 1 \mathrm{SNP}$ c.735C $>\mathrm{G}$ and c. $980 \mathrm{~A}>\mathrm{G}$ in 3,106 dairy cows. Because of the important function of $C X C R 1$ in innate immune responses, mutations in the encoding gene might affect mastitis resistance and milk yield. In our study, SNP c.735C $>$ G tended to associate with Staph. aureus IRCM and was associated with MY. Cows with genotype c.735GG had a lower Staph. aureus IRCM and a higher MY compared with cows with genotype c.735CC. Additionally, 
SNP c.980A $>$ G was associated with Staph. aureus IRCM in heifers. Genotype c.980GG resulted in lower Staph. aureus IRCM compared with genotype c.980AG. The results provide a basis for further research on the relation between $C X C R 1$ polymorphism and pathogenspecific mastitis resistance and MY.

\section{ACKNOWLEDGMENTS}

This research was financed by a $\mathrm{PhD}$ grant (no. 101206) by the Agency for Innovation by Science and Technology in Flanders (IWT Vlaanderen, Brussels, Belgium) and by the Flemish cattle monitoring project (Veepeiler Rund, Drongen, Belgium), headed by the Flemish Animal Health Service (DGZ-Vlaanderen, Drongen, Belgium). The authors thank the Cattle Breeding Association (CRV, Oosterzele, Belgium) for access to DHI records and all participating dairy producers.

\section{REFERENCES}

Bannerman, D. D. 2009. Pathogen-dependent induction of cytokines and other soluble inflammatory mediators during intramammary infection of dairy cows. J. Anim. Sci. 87:10-25. http://dx.doi. org/10.2527/jas.2008-1187.

Bannerman, D. D., M. J. Paape, J. W. Lee, X. Zhao, J. C. Hope, and P. Rainard. 2004. Escherichia coli and Staphylococcus aureus elicit differential innate immune responses following intramammary infection. Clin. Diagn. Lab. Immunol. 11:463-472. http://dx.doi. org/10.1128/CDLI.11.3.463-472.2004.

Barber, M. R., and T. J. Yang. 1998. Chemotactic activities in nonmastitic and mastitic mammary secretions: Presence of interleukin-8 in mastitic but not nonmastitic secretions. Clin. Diagn. Lab. Immunol. 5:82-86.

Barkema, H. W., Y. H. Schukken, T. J. Lam, M. L. Beiboer, G. Benedictus, and A. Brand. 1999. Management practices associated with the incidence rate of clinical mastitis. J. Dairy Sci. 82:1643-1654. http://dx.doi.org/10.3168/jds.S0022-0302(99)75393-2.

Barkema, H. W., Y. H. Schukken, T. J. Lam, M. L. Beiboer, H. Wilmink, G. Benedictus, and A. Brand. 1998. Incidence of clinical mastitis in dairy herds grouped in three categories by bulk milk somatic cell counts. J. Dairy Sci. 81:411-419. http://dx.doi. org/10.3168/jds.S0022-0302(98)75591-2.

Beaudeau, F., V. Ducrocq, C. Fourichon, and H. Seegers. 1995. Effect of disease on length of productive life of French Holstein dairy cows assessed by survival analysis. J. Dairy Sci. 78:103-117. http://dx.doi.org/10.3168/jds.S0022-0302(95)76621-8.

Beecher, C., M. Daly, S. Childs, D. P. Berry, D. A. Magee, T. V. McCarthy, and L. Giblin. 2010. Polymorphisms in bovine immune genes and their associations with somatic cell count and milk production in dairy cattle. BMC Genet. 11:99 http://dx.doi. org/10.1186/1471-2156-11-99.

Detilleux, J. C. 2009. Genetic factors affecting susceptibility to udder pathogens. Vet. Microbiol. 134:157-164. http://dx.doi. org/10.1016/j.vetmic.2008.09.023.

Galvão, K. N., G. M. Pighetti, S. H. Cheong, D. V. Nydam, and R. O. Gilbert. 2011. Association between interleukin-8 receptor-alpha (CXCR1) polymorphism and disease incidence, production, reproduction, and survival in Holstein cows. J. Dairy Sci. 94:20832091. http://dx.doi.org/10.3168/jds.2010-3636.

Goertz, I., C. Baes, C. Weimann, N. Reinsch, and G. Erhardt. 2009. Association between single nucleotide polymorphisms in the CXCR1 gene and somatic cell score in Holstein dairy cattle. J. Dairy Sci 92:4018-4022. http://dx.doi.org/10.3168/jds.2008-1536.

Hertl, J. A., Y. H. Schukken, F. L. Welcome, L. W. Tauer, and Y. T. Grohn. 2014. Pathogen-specific effects on milk yield in repeated clinical mastitis episodes in Holstein dairy cows. J. Dairy Sci. 97:1465-1480. http://dx.doi.org/10.3168/jds.2013-7266.

Hortet, P., F. Beaudeau, H. Seegers, and C. Fourichon. 1999. Reduction in milk yield associated with somatic cell counts up to 600.000 cells $/ \mathrm{mL}$ in French Holstein cows without clinical mastitis. Livest. Prod. Sci. 61:33-42. http://dx.doi.org/10.1016/S03016226(99)00051-2.

Kaplan, N., and B. S. Weir. 1992. Expected behavior of conditional linkage disequilibrium. Am. J. Hum. Genet. 51:333-343.

Keane, O. M., K. E. Budd, J. Flynn, and F. Mccoy. 2013. Pathogen profile of clinical mastitis in Irish milk-recording herds reveals a complex aetiology. Vet. Rec. 173:17 http://dx.doi.org/10.1136/ vr.101308.

Kettritz, R., M. L. Gaido, H. Haller, F. C. Luft, C. J. Jennette, and R. J. Falk. 1998. Interleukin-8 delays spontaneous and tumor necrosis factor-alpha-mediated apoptosis of human neutrophils. Kidney Int. 53:84-91. http://dx.doi.org/10.1046/j.1523-1755.1998.00741.x.

Koivula, M., E. Negussie, and E. A. Mantysaari. 2004. Genetic parameters for test-day somatic cell count at different lactation stages of Finnish dairy cattle. Livest. Prod. Sci. 90:145-157. http://dx.doi. org/10.1016/j.livprodsci.2004.03.004.

Larkin, M. A., G. Blackshields, N. P. Brown, R. Chenna, P. A. McGettigan, H. McWilliam, F. Valentin, I. M. Wallace, A. Wilm, R. Lopez, J. D. Thompson, T. J. Gibson, and D. G. Higgins. 2007. Clustal W and Clustal X version 2.0. Bioinformatics 23:29472948. http://dx.doi.org/10.1093/bioinformatics/btm404.

Leyva-Baca, I., G. Pighetti, and N. A. Karrow. 2008a. Genotypespecific IL8RA gene expression in bovine neutrophils in response to Escherichia coli lipopolysaccharide challenge. Anim. Genet. 39:298-300. http://dx.doi.org/10.1111/j.1365-2052.2008.01711.x.

Leyva-Baca, I., F. Schenkel, J. Martin, and N. A. Karrow. 2008b. Polymorphisms in the $5^{\prime}$ upstream region of the CXCR 1 chemokine receptor gene, and their association with somatic cell score in Holstein cattle in Canada. J. Dairy Sci. 91:407-417. http:// dx.doi.org/10.3168/jds.2007-0142.

Liou, J. W., F. T. Chang, Y. Chung, W. Y. Chen, W. B. Fischer, and H. J. Hsu. 2014. In silico analysis reveals sequential interactions and protein conformational changes during the binding of chemokine CXCL-8 to its receptor CXCR1. PLoS ONE 9: http:// dx.doi.org/10.1371/journal.pone.0094178.

Livak, K. J. 1999. Allelic discrimination using fluorogenic probes and the 5 ' nuclease assay. Genet. Anal. 14:143-149. http://dx.doi. org/10.1016/S1050-3862(98)00019-9.

Ma, Y., C. Ryan, D. M. Barbano, D. M. Galton, M. A. Rudan, and K. J. Boor. 2000. Effects of somatic cell count on quality and shelf-life of pasteurized fluid milk. J. Dairy Sci. 83:264-274. http://dx.doi. org/10.3168/jds.S0022-0302(00)74873-9.

Mehrzad, J., L. Duchateau, and C. Burvenich. 2009. Phagocytic and bactericidal activity of blood and milk-resident neutrophils against Staphylococcus aureus in primiparous and multiparous cows during early lactation. Vet. Microbiol. 134:106-112. http://dx.doi. org/10.1016/j.vetmic.2008.09.001.

Mitchell, G. B., B. N. Albright, and J. L. Caswell. 2003. Effect of interleukin-8 and granulocyte colony-stimulating factor on priming and activation of bovine neutrophils. Infect. Immun. 71:1643-1649. http://dx.doi.org/10.1128/IAI.71.4.1643-1649.2003.

National Mastitis Council. 1999. Laboratory Handbook on Bovine Mastitis. Rev. ed. National Mastitis Council Inc., Madison, WI.

Ogorevc, J., T. Kunej, A. Razpet, and P. Dovc. 2009. Database of cattle candidate genes and genetic markers for milk production and mastitis. Anim. Genet. 40:832-851. http://dx.doi.org/10.1111/ j.1365-2052.2009.01921.x.

Olde Riekerink, R. G. M. O., H. W. Barkema, D. F. Kelton, and D. T. Scholl. 2008. Incidence rate of clinical mastitis on Canadian dairy farms. J. Dairy Sci. 91:1366-1377. http://dx.doi.org/10.3168/ jds.2007-0757. 
Oliveira, L., C. Hulland, and P. L. Ruegg. 2013. Characterization of clinical mastitis occurring in cows on 50 large dairy herds in Wisconsin. J. Dairy Sci. 96:7538-7549. http://dx.doi.org/10.3168/ jds.2012-6078.

Pighetti, G. M., and A. A. Elliott. 2011. Gene polymorphisms: The keys for marker assisted selection and unraveling core regulatory pathways for mastitis resistance. J. Mammary Gland Biol. Neoplasia 16:421-432. http://dx.doi.org/10.1007/s10911-011-9238-9.

Pighetti, G. M., C. J. Kojima, L. Wojakiewicz, and M. Rambeaud. 2012. The bovine $C X C R 1$ gene is highly polymorphic. Vet. Immunol. Immunopathol. 145:464-470. http://dx.doi.org/10.1016/j. vetimm.2011.09.012.

Santos, M. V., Y. Ma, and D. M. Barbano. 2003. Effect of somatic cell count on proteolysis and lipolysis in pasteurized fluid milk during shelf-life storage. J. Dairy Sci. 86:2491-2503. http://dx.doi. org/10.3168/jds.S0022-0302(03)73843-0.

Schukken, Y. H., J. Gunther, J. Fitzpatrick, M. C. Fontaine, L. Goetze, O. Holst, J. Leigh, W. Petzl, H. J. Schuberth, A. Sipka, D. G. E. Smith, R. Quesnell, J. Watts, R. Yancey, H. Zerbe, A. Gurjar, R. N. Zadoks, and H. M. Seyfert. 2011. Host-response patterns of intramammary infections in dairy cows. Vet. Immunol. Immunopathol. 144:270-289. http://dx.doi.org/10.1016/j. vetimm.2011.08.022.

Schukken, Y. H., D. J. Wilson, F. Welcome, L. Garrison-Tikofsky, and R. N. Gonzalez. 2003. Monitoring udder health and milk quality using somatic cell counts. Vet. Res. 34:579-596. http://dx.doi. org/10.1051/vetres:2003028.

Seegers, H., C. Fourichon, and F. Beaudeau. 2003. Production effects related to mastitis and mastitis economics in dairy cattle herds. Vet. Res. 34:475-491. http://dx.doi.org/10.1051/vetres:2003027.

Smit, A. F. A., R. Hubley, and P. Green. 2010. RepeatMasker Open3.0. Accessed January 18, 2013. http://www.repeatmasker.org.
Sodeland, M., M. P. Kent, H. G. Olsen, M. A. Opsal, M. Svendsen, E. Sehested, B. J. Hayes, and S. Lien. 2011. Quantitative trait loci for clinical mastitis on chromosomes 2, 6, 14 and 20 in Norwegian Red cattle. Anim. Genet. 42:457-465. http://dx.doi.org/10.1111/ j.1365-2052.2010.02165.x.

Van Poucke, M., J. Vandesompele, M. Mattheeuws, A. Van Zeveren, and L. J. Peelman. 2005. A dual fluorescent multiprobe assay for prion protein genotyping in sheep. BMC Infect. Dis. 5:13 http:// dx.doi.org/10.1186/1471-2334-5-13.

Verbeke, J., S. Piepers, L. J. Peelman, M. Van Poucke, and S. De Vliegher. 2012. Pathogen-group specific association between CXCR 1 polymorphisms and subclinical mastitis in dairy heifers. J. Dairy Res. 79:341-351. http://dx.doi.org/10.1017/S0022029912000349.

Verbeke, J., S. Piepers, K. Supré, and S. De Vliegher. 2014. Pathogenspecific incidence rate of clinical mastitis in Flemish dairy herds, severity, and association with herd hygiene. J. Dairy Sci. 97:69266934.

Windig, J. J., W. Ouweltjes, J. Ten Napel, G. de Jong, R. F. Veerkamp, and Y. de Haas. 2010. Combining somatic cell count traits for optimal selection against mastitis. J. Dairy Sci. 93:1690-1701. http:// dx.doi.org/10.3168/jds.2009-2052.

Wolff, C., M. Espetvedt, A. K. Lind, S. Rintakoski, A. Egenvall, A. Lindberg, and U. Emanuelson. 2012. Completeness of the disease recording systems for dairy cows in Denmark, Finland, Norway and Sweden with special reference to clinical mastitis. BMC Vet. Res. 8:131 http://dx.doi.org/10.1186/1746-6148-8-131.

Youngerman, S. M., A. M. Saxton, S. P. Oliver, and G. M. Pighetti. 2004. Association of CXCR2 polymorphisms with subclinical and clinical mastitis in dairy cattle. J. Dairy Sci. 87:2442-2448. http://dx.doi.org/10.3168/jds.S0022-0302(04)73367-6.

Zuker, M. 2003. Mfold web server for nucleic acid folding and hybridization prediction. Nucleic Acids Res. 31:3406-3415. 